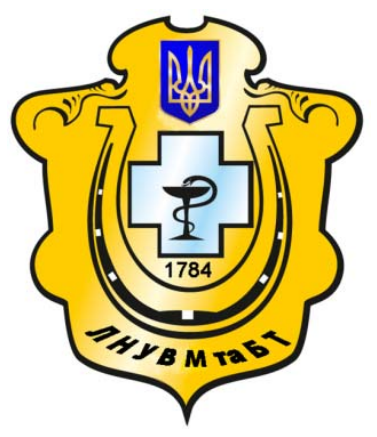

Науковий вісник Львівського національного університету ветеринарної медицини та біотехнологій імені С.З. Гжицького

Scientific Messenger of Lviv National University of Veterinary Medicine and Biotechnologies named after S.Z. Gzhytskyj

doi:10.15421/nvlvet7616

ISSN 2519-2701 print

ISSN 2518-1327 online

$\underline{\text { http://nvlvet.com.ua/ }}$

УДК 631.1.027:631.115

\title{
Становлення маркетингової діяльності у сільськогосподарських підприсмствах України
}

\author{
C.I. Поперечний \\ stepany2008@ukr.net
}

\begin{abstract}
Львівський національний університет ветеринарної медищини та біотехнологій імені С.3. Гжицького, вул. Пекарська, 50, м. Львів, 79010, Украӥна
\end{abstract}

\begin{abstract}
Аналізуються проблеми маркетингової діяльності сільськогосподарських підприємств. Показано, що основними з них $є$ неналежна сформованість ринку і його інфраструктури. Крім того, вони посилюються взаємосуперечливими пропозиціями щодо такої діяльності, запозиченими у різних наукових школах та течіях, щь застосовувались у різні історичні періоди в економічно розвинутих краӥн. Не здійснюється ринкове генерування иін. Ціни дуже мінливі. Через високий ризик не оформляються кредити банку. Кошти не інвестиуються у галузі з тривалою окупністю капіталу. Кадровий потенціал підприємств переважно недостатній для дослідження і прогнозування ринку. Інформація за результатами таких досліджень органами державного управління сільським господарством та науковими установами не передається сільськогосподарським підприсмствам. Без такої інформації неможливо розробляти та здійснювати обтрунтовану товарну політику. Державна фінансова підтримка лише частково компенсує неефективні маркетингові рішення суб'єктів господарювання. Основними виробниками багатьох видів продукиії є особисті селянські господарства, де собівартість продукиіі не визначається і вони менше, ніж сільськогосподарські підприємства, чутливі до чинників ринкового середовища. Пропонується державну підтримку сільського господарства спрямовувати на формування ринкового середовища. Показано, щзо така підтримка дозволить здійснювати досконаліму маркетингову діяльність окремими суб'єктами господарювання $і \epsilon$ ефективнішою, ніж пряма державна фінансова підтримка.

Ключові слова: маркетинг, аграрний ринок, інфраструктура ринку, маркетингові дослідження, маркетингова товарна політика, маркетингові канали, ціна, ринкове генерування циін.
\end{abstract}

\section{Становление маркетинговой деятельности в сельскохозяйственных предприятиях Украины}

\author{
С.И. Поперечный \\ stepany2008@ukr.net
}

Львовский национальный университет ветеринарной медицины и биотехнологий имени С.3. Гжиџкого, ул. Пекарская, 50, г. Львов, 79010, Украина

\begin{abstract}
Анализируются проблемы маркетинговой деятельности сельскохозяйственных предприятий. Показано, что основными из них являются ненадлежащая сформированность рынка и его инфраструктуры. Кроме того, они усиливаются взаимопротиворечащими предложениями по такой деятельности, заимствованныли в различных научных школах и течениях, которые применялись в разные исторические периоды в экономически развитых странах. Не осуществляется рыночное генерирования иен. Цены очень изменчивы. Средства не инвестируются в отрасли с длительной окупаемостью капитала. Кадровый потенциал предприятий преимущественно недостаточен для исследования и прогнозирования рынка. Информаиия по результатам таких исследований органами государственного управления сельским хозяйством и научными учреждениями не передается сельскохозяйственным предприятиям. Без такой информации невозможсно разрабатывать и осуществлять обоснованную товарную политику. Государственная финансовая поддержка лишь частично компенсирует неэффективные маркетинговые решения предприятий. Основными производителями многих видов продукиии являются
\end{abstract}

Citation:

Poperechnuy, S. (2017). Formation of marketing activities in agricultural enterprises of Ukraine. Scientific Messenger LNUVMBT named after S.Z. Gzhytskyj, 19(76), 82-85. 
личные крестьянские хозяйства, где себестоимость продукиии не определяется и они меньше, чем сельскохозяйственные предприятия чувствительны к факторам рыночной среды. Предлагается государственную поддержку сельского хозяйства направлять на формирование рыночной среды. Показано, что такая поддержка является более эффективной, чем прямая государственная финансовая поддержка. Она способствует улучшению маркетинговой деятельность отдельных субъектов хозяйствования и повышению общей экономической эффективности сельского хозяйства.

Ключевые слова: маркетинг, аграрный рынок, инфраструктура рынка, маркетинговые исследования, маркетинговая товарная политика, маркетинговые каналь, цена, рыночное генерирование цен.

\title{
Formation of marketing activities in agricultural enterprises of Ukraine
}

\author{
S. Poperechnuy \\ stepany2008@ukr.net \\ Lviv National University of Veterinary Medicine and Biotechnologies named after S.Z. Gzhytskyi, \\ Pekarska Str., 50, Lviv, 79010, Ukraine
}

The conditions and opportunities of marketing of agricultural enterprises are analyzed. It is shown that marketing activities on the basis of systematic agriculture today most economically developed countries arose as a way to counter monopolistic tendencies in the procurement of products. To do this, set up marketing cooperatives. On the basis of cooperative formed the infrastructure of agrarian market was founded. In conjunction with state regulation of prices overcome the crisis. In Ukraine, the most established marketing cooperatives operate formally. They can't provide all stabilization methods of state regulation of prices after 1991. Prices are variable. Due to the high risk is not issued bank loans. Funds are not invested in the field of long-term return on investment capital. Human resources companies mostly insufficient for research and market forecasting. Information on the results of such studies by government agricultural research institutions and not transferred to farms. Without such information it is impossible to develop and implement a reasonable commercial policy. State financial support only partly compensates for ineffective decisions entities in this regard. Significant differentiation trend farmers in size with ousted medium-sized enterprises. Large companies form their own distribution channels focused on products and expert external market prices, which are stalishymy compared to the purchase prices for agricultural products in Ukraine. The main producers of many products are individual farms, where production costs are not defined and are smaller than farms sensitive to factors of market environment. The necessity of priority direction of state support for the formation of the agricultural market, its infrastructure, enhance the generation of market prices. Such support is more resulted than direct government financial support.

Key words: marketing, agricultural market, market infrastructure, market research, marketing product policy, marketing channels, price, market generation prices.

\section{Вступ}

Маркетингова діяльність є природною реакцією суб'єкта господарювання на чинники ринкового середовища, у якому він функціонує. Така діяльність є вічним супутником товарного виробництва. Історично у світовій практиці на початкових етапах становлення ринкових відносин інтуїтивно застосовувались основні елементи адаптації до ринку, які трансформувались у міру розвитку ринкових відносин і набуття досвіду такої діяльності. Популяризація маркетингу в сільському господарстві України у першій половині 90-х років на початковому етапі реформування аграрного сектора економіки поєднувалась 3 набутим досвідом та системним підходом до такої діяльності у економічно розвинутих країнах. У вітчизняних наукових виданнях того періоду пропонувались усі можливі підходи до застосування маркетингу, запозичені у зарубіжних виданнях, як правило, без урахування особливостей сільського господарства України, рівня сформованості ринкових відносин та проблем, які слід вирішувати. Пропонувались напрями, характерні для різних історичних підходів, різних наукових шкіл та течій. Значною кількістю таких пропозицій спровоковано багатоплановість підходів до застосування аграрного маркетингу, взаємну суперечливість сутності та доцільних напрямів маркетингової діяльності, невизначеність щодо цього практиків господарювання.

Актуальність проблем застосування аграрного маркетингу посилюється в міру розвитку ринкових від- носин, активізації процесів міжнародної інтеграції України. Цим зумовлено значну увагу до них аграрних економістів. Дослідженню проблем маркетингу присвятили свої праці такі автори, як Грановська В.Г. (Hranovska, 2017), Кашуба Ю.П. (Yanyshyn and Kashuba, 2014), Козак Л.В. (Kozak, 2014), Кужель В.В. (Kuzhel, 2015), Олійник О.В., Скоромна О.Ю. (Oliinyk and Skoromna, 2016), Романова Л.В. (Romanova, 2013), Янишин Я.С. Все ж до цього часу не сформовано загальноприйнятих підходів до практичного застосування аграрного маркетингу.

Метою статті є виявлення чинників, що стримують практичне застосування аграрного маркетингу в Україні, знецінення його сприйняття практиками господарювання. Для досягнення цієї мети вирішувались такі завдання, як дослідження ринкового середовища сільськогосподарських підприємств, аналізу їх ринкових можливостей, впливу рівня та співвідношення цін на застосування окремих елементів маркетингу та ефективне використання ресурсів сільського господарства.

\section{Матеріал і методи досліджень}

Застосовувались загальноприйняті методи наукових досліджень. Монографічний метод застосовувався для виявлення умов i можливостей маркетингової діяльності сільськогосподарських підприємств. Статистичні методи використовувались для аналізу впли- 
ву основних чинників ринкового середовища на результати маркетингової діяльності. Джерелом інформації були дані Державної служби статистики України.

\section{Результати та їх обговорення}

Центральною проблемою сільського господарства $\epsilon$ ціна на продукцію сільськогосподарських підприємств та засоби виробництва для сільського господарства. Ціни як на засоби виробництва, так і на продукцію уже на ранніх етапах становлення ринкових відносин формуються під монопольним впливом окремих структур, провокуючи кризові явища у сільському господарстві, а відтак через скорочення попиту на засоби виробництва та дефіцит сировини для переробки у суміжних із сільським господарством галузях провокує загальні кризові явища в суспільстві. Цим зумовлене намагання державних органів управління сільським господарством у більшості нині економічно розвинутих країн здійснювати регулювання цін, яке не могло бути результативним без системних засад маркетингової діяльності виробників сільськогосподарської продукції. Така діяльність того періоду мала чітко виражений збутовий характер. Вона зумовила поширені визначення сутності маркетингу, що зустрічаються до цього часу, як збутової діяльності. Монопольний вплив окремих структур у сфері закупівель того періоду долався створенням невеликими сільськогосподарськими виробниками збутових кооперативів. Подальший розвиток таких кооперативних формувань спрямовувався на створення у зонах виробництва сировини оптових ринків сільськогосподарської продукції, формування на кооперативних засадах переробних потужностей та торговельних організацій. Виникали територіальні продуктові комплекси, створені сільськогосподарськими виробниками, формувались зони виробництва сировини, структурувався на основі цього аграрний ринок. В Україні більшість створених обслуговуючих кооперативів функціонують формально. На кооперативних засадах канали розподілу не формуються. Такі кооперативи не здійснюють помітного впливу на ціну. Без таких кооперативів безрезультатними були і спроби державного регулювання цін на сільськогосподарську продукцію. Визначальним чинником впливу на ціну були монопольні тенденції закупівельних організацій. В поєднанні з впливом об'єктивних ринкових чинників формувалось ринкове середовище, характерною ознакою якого є високий рівень мінливості цін (рис. 1). Ціни на сільськогосподарську продукцію настільки мінливі, що прогнозувати очікуваний їх рівень неможливо. Відповідно неможливо розробляти не тільки маркетингові стратегії, а й приймати обгрунтовані поточні рішення щодо маркетингової товарної політики. Через високу ризиковість не можуть оформлятись банківські кредити. Кошти не інвестуються у таку капіталомістку галузь $з$ тривалою окупністю інвестицій, як скотарство.

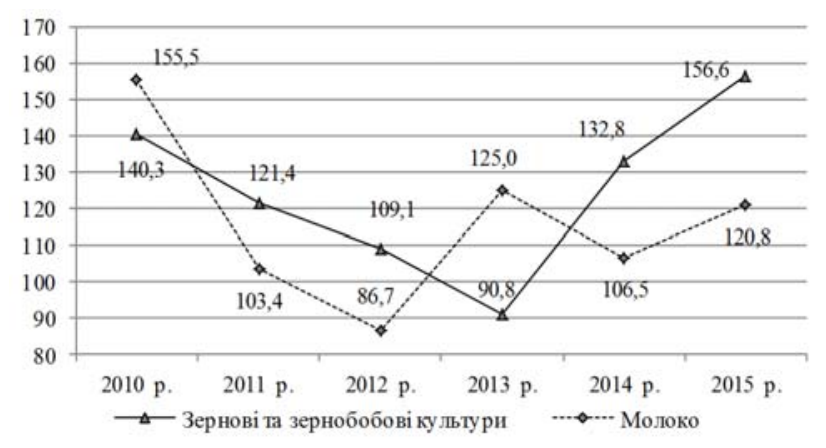

Рис. 1. Індекси цін реалізації зернових і зернобобових культур та молока сільськогосподарськими підприсмствами України, у відсотках до попереднього року

Джерело інформації: дані Державної служби статистики України

Поголів'я великої рогатої худоби у сільськогосподарських підприємствах України за 2010-2015 роки скоротилось $з$ 1526,4 до 1270,5 тисяч голів (рис. 2).

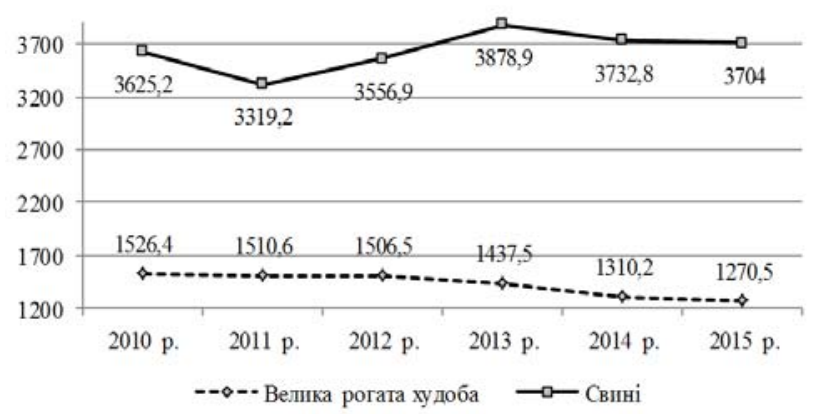

Рис. 2. Поголів'я тварин у сільськогосподарських підприсмствах України на кінець року, тис. гол. Джерело інформації: дані Державної служби статистики України

Прискорено розвиваються галузі з коротким періодом виробництва і швидкою окупністю капіталу. Поголів'я свиней, наприклад, за 2011-2013 роки зросло 3 3319,2 до 3878,9 тис. гол. Збільшення поголів'я свиней призводило до зростання пропозиції свинини, а зростання пропозиції - до зниження ціни і втрати прибутку. Періоди збільшення поголів'я корів чергувались $з$ такими ж періодами його зменшення, недовикористанням потужностей і вимушеним покидання галузі. Наприклад, маса прибутку у розрахунку на 100 гривень поточних затрат на виробництво свинини у 2013 році складала 0,2 гривень, що при існуючих темпах інфляції не забезпечувало навіть простого відтворення. А така приваблива у попередні роки галузь, як виробництво птиці, за 2012-2015 роки була збитковою (табл. 1).

Державні цільові програми розвитку сільського господарства розроблялись, однак інформація щодо пріоритетного розвитку окремих галузей до сільськогосподарських виробників не доводилась. На компенсаційній основі здійснювалась підтримка нерентабельних галузей, але така підтримка надавалась після одержання збитків. При цьому вона не повною мірою компенсувала такі збитки. 
Прибуток (+), збитки (-) у розрахунку на 100 гривень поточних затрат на виробництво продукції у сільськогосподарських підприсмствах України, грн.

\begin{tabular}{|c|c|c|c|c|}
\hline Продукція & 2012 p. & 2013 p. & 2014 p. & $2015 \mathrm{p}$. \\
\hline Зернові та зернобобові культури & 15,8 & 2,4 & 25,7 & 42,6 \\
\hline Насіння соняшнику & 44,9 & 28,2 & 36,7 & 78,4 \\
\hline $\begin{array}{l}\text { Цукрові буряки } \\
\text { (фабричні) }\end{array}$ & 15,9 & 3,1 & 17,8 & 27,7 \\
\hline Овочі & $-0,6$ & 7,5 & 14,5 & 32,0 \\
\hline Картопля & $-17,4$ & 22,4 & 9,9 & 24,6 \\
\hline Плоди та ягоди & 9,6 & 127,5 & 65,8 & 58,3 \\
\hline Молоко & 1,8 & 13,1 & 11,1 & 12,7 \\
\hline Велика рогата худоба на м'ясо & $-28,3$ & $-41,3$ & $-34,5$ & $-16,9$ \\
\hline Свині на м'ясо & 1,8 & 0,2 & 5,6 & 12,6 \\
\hline Птиця на м'ясо & $-2,4$ & $-5,9$ & $-12,6$ & $-5,4$ \\
\hline
\end{tabular}

Джерело інформації: дані Державної служби статистики України

Через несформованість інфраструктури аграрного ринку суб'єкти господарювання не можуть формувати прийнятних для них каналів розподілу. Майже не функціонують аграрні біржі. Діючі в Україні оптові ринки сільськогосподарської продукції більш прийнятні для посередницьких організацій, ніж для виробників продукції. Тут не здійснюються акційні торги. Переважає роздрібна та дрібнооптова торгівля.

Повноцінну маркетингову діяльність в ринковому середовищі України здійснювати проблемно. Через це намітилась тенденція поляризації виробників за розмірами. Основними виробниками багатьох видів продукції є особисті селянські господарства, у яких собівартість продукції не калькулюється, і вони менш, ніж сільськогосподарські підприємства, чутливі до ціни та ринкового середовища. Виробляти продукцію 3 дотриманням належних санітарних норм тут неможливо. Це стримує можливості виведення продукції на зовнішні ринки та міжнародні інтеграції України. Поширення набувають особливо великі за розмірами господарства голдингового типу при витісненні середніх за розмірами підприємств. Уже в даний час рівень концентрації виробництва зерна, насіння соняшнику та ріпаку в Україні $є$ рекордним, порівняно 3 іншими країнами. Чітко відстежується посилення процесів виробництва сировини на експорт в поєднанні з вимушеним імпортом продуктів переробки.

\section{Висновки}

Ефективно маркетингова діяльність суб'єктів господарювання у сільському господарстві можлива за умови належної сформованості ринку та його інфраструктури, ринкового генерування цін та їх стабілізації. Без цього вимагається постійне збільшення обсягів прямої державної фінансової підтримки виробників, яка лише частково покриває недоодержаний прибуток. Результативнішою є підтримка процесів розбу- дови ринку в поєднанні з стимулюванням інтеграційних процесів суб'єктів господарювання, об'єднаних спільним ланцюгом руху товарної маси.

Перспективи подальших досліджень. Актуальними та практично значущими є подальші дослідження умов та можливостей здійснення виробниками сільськогосподарської продукції ефективної маркетингової діяльності 3 урахуванням міжнародних зобов'язань України та особливостей вітчизняного сільського господарства.

\section{Бібліографічні посилання}

Hranovska, V.H. (2017). Heomarketynh u systemi upravlinnia zbutovoiu diialnistiu ahrarnykh pidpryiemstv. Ekonomika APK. 1, 37-44 (in Ukrainian).

Kozak, L.V. (2014). Kryterii kupivelnoi povedinky spozhyvachiv na rynku produktiv kharchuvannia $\mathrm{V}$ Ukraini. Ekonomika APK. 5, 30-36 (in Ukrainian).

Kuzhel, V.V. (2015). Marketynh u pidvyshchenni sotsialnoi vidpovidalnosti ahrarnykh pidpryiemstv. Ekonomika APK. 4, 41-46 (in Ukrainian).

Oliinyk, O.V., Skoromna, O.Iu. (2016). Intehralna otsinka efektyvnosti upravlinnia formuvanniam prybutku vid realizatsii produktsii $\mathrm{V}$ silskohospodarskykh pidpryiemstvakh. Ekonomika APK. 4, 81-84 (in Ukrainian).

Romanova, L.V. (2013). Do problemy formuvannia suchasnoi modeli marketynhu v Ukraini. Ekonomika APK. 5, 102-107 (in Ukrainian).

Yanyshyn, Ya.S., Kashuba, Yu.P. (2014). Marketynh yak systema upravlinnia vyrobnycho-zbutovoiu diialnistiu ahrarnykh pidpryiemstv. Ekonomika APK. 3, 61-65 (in Ukrainian).

Стаття надійшла до редакиії 1.03.2017 